\title{
JORNALISMO: UMA OPÇÃO
}

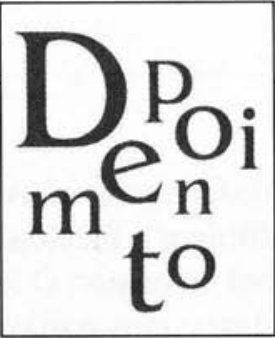

\section{Jornalismo a serviço da cidadania, opondo-se a interesses particulares e à subserviência ao mercado}

Jornalismo é um serviço público essencial, que existe para informar uma parte da sociedade sobre o que a outra parte está fazendo.

Jornalismo é o resultado do trabalho produzido pelo repórter, o sujeito que vai aos lugares para saber o que está acontecendo, abre bem os olhos e os ouvidos, pergunta muito e, depois, conta o que viu e ouviu aos que não puderam estar no local dos fatos.

Jornalismo não é uma Ciência exata. Trata-se de uma atividade muito simples. Alia a técnica elementar dos antigos contadores de histórias à arte de descobrir o que está acontecendo de novo, para reproduzir os fatos de uma forma capaz de despertar o interesse dos outros, e todos possam entender.

Em resumo, foram estas três singelas lições sobre o nosso ofício que aprendi ao longo de mais de três décadas de trabalho como repórter de jornal e, de 1996 para cá, como diretor de jornalismo de TV.

Ao longo deste tempo todo, vi muita coisa mudar nas redações e no mundo, claro. Mas a natureza do trabalho do jornalista continua exatamente a mesma, seja qual for sua função ou veículo: fornecer informações confiáveis à sociedade.

Quero deixar bem claro que esta é uma visão subjetiva, pessoal, intransferível, já que cada jornalista tem sua própria definição sobre o nosso trabalho.

Há mil e uma maneiras de se exercer o jornalismo e, por isșo, acho que, antes mesmo de escrevermos a primeira matéria, devemos definir o que queremos desta profissão, qual é o nosso objetivo.

Num dos meus livros destinados aos estudantes de Comunicação, $A$ prática da reportagem ${ }^{1}$, escrevi que ao nos encaminharmos para o jornalismo estamos fazendo, mais do que uma opção profissional, uma opção de vida.

Foi o que fiz ainda adolescente, nos anos 60 , quando não era preciso cursar uma faculdade e esperar o diploma para poder ser jornalista (fui da primeira turma da

\section{O AUTOR}

\section{Ricardo Kotscho}

Jornalista e Diretor de jornalismo na TV Bandeirantes e no Canal 21.

1. KOTSCHO, R. A prática da reportagem. São Paulo: Ática, 1986. (Coleção Fundamentos.) 
Escola de Comunicações e Artes - ECA, em 1967, mas não tive tempo de terminar a faculdade até hoje). Queria mesmo era ser jogador de futebol ou cantor. $\mathrm{O}$ teste vocacional me indicou o sacerdócio.

Mas, como gostava de namorar, e não tinha nenhum talento para realizar meus dois sonhos de moleque, acabei indo trabalhar numa banca de jornal. Das bancas de Pinheiros e, depois, de Santo Amaro, inebriado pelo cheiro de tinta no papel impresso exalando das manchetes dos jornais, recolhi o gosto pela leitura das notícias e reportagens. O passo seguinte foi criar coragem para pedir emprego nos jornais de bairro.

O que nos move? Esta é a pergunta primeira que devemos nos fazer. Tentar respondê-la com a maior sinceridade possível é a única maneira de evitar frustações futuras. Se meu principal objetivo fosse ganhar dinheiro e ficar famoso, deveria ter insistido mais com a música e o futebol, já que está cheio de exemplos de pernas-depau e desafinados que se deram bem na vida.

Além disso, devem existir mais jornaleiros realizados na vida e satisfeitos com seu ofício num país em que as pessoas valem mais pelo que têm do que pelo que são.

O que me movia, em 1964, quando fui trabalhar na Folha Santamarense e, depois, na Gazeta de Santo Amaro, e me move até hoje, é poder fazer do trabalho de jornalista instrumento vital - não só de informação, mas de transformações - numa sociedade injusta e de profundas desigualdades como a nossa.

Hoje constato que, não fosse a obtusidade e a hipocrisia da Igreja Católica, que proíbe padre de se casar, minha trajetória de vida não teria sido muito diferente. Se tivesse seguido a indicação do teste vocacional, não por acaso feito num colégio de padres, poderia de outra forma contribuir para denunciar o que está errado e louvar o que bem merece, como diz a canção.

O jornalismo, afinal, deve ser um serviço sempre voltado para atender às necessidades do próximo, de preferência para a maioria dos próximos e, mais ainda, para aqueles deserdados do mercado de trabalho, da Justiça, dos direitos básicos da cidadania, enfim.

Pois não é exatamente isto que defendem meus amigos da Teologia da Libertação, desafiando a hierarquia do Vaticano, mais ou menos como meia dúzia de três ou quatro colegas jornalistas fazem em relação aos donos do poder da mídia?

Professores, médicos, engenheiros, advogados, delegados de polícia ou assistentes sociais também podem fazer de sua profissão um sacerdócio, dar a ela uma função social - qualquer um pode. A diferença, em relação aos jornalistas, é que nós podemos fazer isso, 
pela própria natureza da profissão, de uma forma mais massiva e mais rápida, graças ao alcance e poder dos meios de comunicação.

\section{O QUE NOS MOVE?}

Antes que algum eventual leitor comece a rir discretamente deste depoimento, um aviso. Sei que tudo isso que escrevi aí acima pode parecer muito ingênuo e utópico diante da realidade do nosso mercado persa da comunicação, nestes tempos globalizadores da pefelândia triunfante no império tucano do leve vantagem em tudo.

O que move hoje a maioria absoluta dos veículos e dos profissionais de Comunicação, como todos sabemos, é exatamente o contrário do que penso que deveria ser. Ou seja, o interesse particular sempre colocado acima do coletivo, resultado de um jornalismo subserviente diante do poder e arrogante, implacável com os que habitam os andares de baixo da pirâmide social.

Nem por isso vou aderir ao jornalismo de resultados e deixar de lutar pelo resgate do que é mais sagrado neste ofício: a reportagem que vai fundo, com liberdade para contar uma realidade que os chamados poderes constituídos de todas as latitudes procuram esconder.

A pauta da nossa grande imprensa já não nasce nas ruas e nos campos, nas escolas e nas fábricas, entrando nas redações sem pedir licença. Chega como prato feito dos gabinetes oficiais para eternizar os donos do poder e afastar qualquer risco de mudança.

Mudar para quê, se acima da identidade ideológica que une os donos do poder político, econômico e da mídia num pensamento único, há uma aliança de interesses comerciais, verbas publicitárias e bons negócios privatizantes para todos? É um negócio tão bom que sobra também um trocado para os jornalistas preocupados unicamente com suas carreiras e seu bem-estar. $\mathrm{O}$ resto que se dane.

Se alguém tiver a ousadia de não se submeter a este pensamento único que domina nossas redações é logo chamado, no mínimo, de poeta ou maluco. Mesmo assim, vale a pena ser jornalista, a melhor profissão do mundo para quem não se conforma com o mundo como ele é.

Ainda não inventaram outra profissão mais generosa para quem não veio ao mundo a passeio e acredita ser possível, com o seu trabalho, fazer do amanhã um dia diferente e melhor do que ontem.

Por mais poderosos que sejam os donos dos meios de comunicação, eles sozinhos não colocam um telejornal no ar, nem jornais e revistas nas bancas. Vão sempre precisar de nós, jornalistas, e cabe- 
rá a nós decidir o que pretendemos fazer da nossa profissão. Se hoje ela está degradada, não podemos colocar a culpa nos outros, nem achar que este é um quadro irreversível, que não tem outro jeito.

Já que vivemos sob a ditadura do mercado, minha esperança é que os leitores/ouvintes/telespectadores rejeitem os veículos capachos do poder e seus jornalistas amestrados. O jornalismo, como a vida de cada um de nós, é feito de ciclos, de marés cheias e vazantes, de altos e baixos.

O importante é nunca perder de vista o que nos move ao sair de casa cada dia de manhã rumo à redação. Se não for possível um trabalho decente e com prazer, sempre recomendo aos jovens colegas que demitam a empresa antes de perder seus princípios.

Como se espera que um jornalista saiba ler e escrever, certamente ele não vai morrer de fome se tiver que mudar de ramo para ganhar a vida sem vender sua alma.

É melhor voltar a ser jornaleiro ou ler e escrever cartas para analfabetos como no filme Central do Brasil do que contribuir para a degradação de um ofício que só tem razão de existir se for possível levá-lo às últimas conseqüências.

Colocar o jornalismo a serviço do bem comum e da transformação da nossa sociedade em algo mais humano do que um acampamento de interesses cercado de misérias e miseráveis por todos os lados é o desafio diário de quem faz esta opção de vida.

\section{PERFIL}

Ricardo Kotscho, 50 anos, 34 de carreira, é Diretor de Jornalismo da TV Bandeirantes - SP e do Canal 21. Nasceu em São Paulo, cursou Rádio e TV na Escola de Comunicações e Artes da USP; Ciências Sociais, também na USP; Economia, no Mackenzie, mas não concluiu nenhuma das três faculdades.

Começou a trabalhar como repórter, em 1964, na Folha Santamarense, depois passou para a Gazeta de Santo Amaro, ambos jornais de bairro de São Paulo, onde exerceu várias funções, de vendedor de anúncios a repórter.

Em 1967, entrou para a grande imprensa pelas portas do jornal $O$ Estado de S. Paulo, onde ficou até 1977. Lá foi repórter, pauteiro, chefe de reportagem, editor de esportes e de cidades, e repórter especial.

No mesmo ano, foi para a Europa como correspondente do Jornal do Brasil baseado em Bonn, então capital da República Federal da Alemanha. Cobriu várias eleições, quedas de governo, morte e eleição de dois papas, acordo nuclear, terrorismo, encontros de cúpula. 
No final de 1978, voltou para o Brasil e foi trabalhar na equipe de Mino Carta na IstoÉ, a mesma que no ano seguinte lançou o Jornal da República. Com o fechamento do jornal, foi para a Folha de S. Paulo, em 1980, como repórter especial. Em 85, passou pela TV Globo, onde trabalhou no programa Globo Rural, voltando no final do mesmo ano para a Folha.

Em 1986, foi para a sucursal do Jornal do Brasil, saiu em 1989 para fazer a assessoria de imprensa de Lula na campanha presidencial e retornou ao $J B$, em 1990, permanecendo lá até 1993, como repórter especial. Criou as Caravanas da Cidadania de Lula e voltou a coordenar a área de comunicação na campanha presidencial de 1994.

Em 95, foi para o Sistema Brasileiro de Televisão - SBT, fazendo parte da equipe que criou o SBT Repórter, prêmio APCA de melhor programa do ano. No começo de 1996, assumiu a direção de jornalismo da rede CNT/Gazeta, em Curitiba. Voltou para São Paulo no início de 1998 para assumir a direção de Jornalismo da TV Bandeirantes - SP e do Canal 21.

Ganhou quatro vezes o Prêmio Esso de Jornalismo, duas vezes o Vladimir Herzog de Direitos Humanos, uma vez o prêmio Abril, entre outros.

Tem 15 livros publicados. Entre eles: A prática da reportagem, $A$ aventura da reportagem, em parceria com Gilberto Dimenstein, e Repórteres, vários autores, organizado por Audálio Dantas².

Foi diretor do Sindicato dos Jornalistas de São Paulo, vicepresidente da Federação Nacional dos Jornalistas e conselheiro da Associação Brasileira de Imprensa.

É membro da Comissão de Justiça e Paz da Arquidiocese de São Paulo e do Conselho Editorial da revista Teoria e Debate.

Foi colaborador de diversas publicações: $O$ Cruzeiro, Opinião, Movimento, Caros Amigos, Caminhos da Terra, O São Paulo, entre outras.

Participou de mais de 200 seminários e encontros sobre Jornalismo e foi paraninfo ou patrono de 28 turmas de Comunicação em diferentes Estados do país. Aposentou-se como jornalista em março de 1998, foi chamado de vagabundo, mas continua trabalhando 14 horas por dia. É casado com a socióloga Mara Kotscho, e tem duas filhas: Mariana (jornalista) e Carolina (produtora de cinema e dona de boteco).

2. KOTSCHO, R. A prática da reportagem. op. cit. DIMENSTEIN, G. A aventura da reportagem. São Paulo: Summus. 1990. DANTAS, A. (org.) Repórteres. São Paulo: Senac, 1998. 
Resumo: Ricardo Kotscho trata do jornalismo como serviço essencial, que deveria ser independente de interesses particulares e comerciais. Fala de sua opção profissional como opção de vida pois, para ele, o jornalismo é como um sacerdócio, tem função social. Em 34 anos de carreira foi repórter, correspondente internacional, assessor de imprensa e, atualmente, é diretor de jornalismo na TV Bandeirantes - SP e no Canal 21.

Palavras-chave: jornalismo, repórter, Ricardo Kotscho, profissão, função social
Abstract: Ricardo Kotscho deals with journalism as an essential public service that should be independent from private and commercial interests. He talks about his professional option as a life option since, to him, journalism is like priesthood, it has a social function. During his 34-year career, he was a reporter, international correspondent, and a press assistant. He is currently the director of journalism at TV Bandeirantes/SP and also at Canal 21 (Channel 21).

Key words: journalism, reporter, Ricardo Kotscho, profession, social function 